\title{
MENJADI VIRAL DAN TERKENAL DI MEDIA SOSIAL, PADAHAL KORBAN CYBERBULLYING: SUATU KERUGIAN ATAU KEUNTUNGAN?
}

\section{Dominikus David Biondi Situmorang*}

*Universitas Katolik Indonesia Atma Jaya

DOI: https://doi.org/10.21009/JPPP.081.02

\author{
Alamat Korespondensi: \\ david.biondi@atmajaya.ac.id
}

\begin{abstract}
The phenomenon of being viral and well-known in Indonesia, which begins with experience as a victim of cyberbullying, has a psychological and negative impact that is quite complex psychologically. Methods: Review e-journals obtained through Google Scholar, Springer Link, ProQuest, Ebsco Host, Cambridge Core, and Taylor and Francis Online, during October 2018. Results: There are 4 major themes identified in the negative psychological impact of victims of cyberbulling, e.g.: (1) emotional regulation, (2) stress, (3) depression, and (4) loneliness. There are 3 major themes identified in the psychologically positive impact of cyberbulling victims who become viral and well-known, e.g.: (1) happiness, (2) life satisfaction, and (3) subjective wellbeing. Conclusions: Based on this literature review, cyberbullying is noted to have psychological disadvantages and benefits for victims. In Indonesia, being one of the victims of cyberbullying on social media in Indonesia is quite unique, because the effect can be viral and famous.
\end{abstract}

\section{Keywords}

viral, popular, famous, victim, cyberbullying, social media, Indonesia, negative psychological impact, positive psychological impact

\section{Pendahuluan}

Cyberbullying merupakan sebuah perilaku bullying yang terjadi di dalam berbagai media teknologi (Olweus, 2012; Smith, del Barrio, \& Tokunaga, 2012; Ybarra, Boyd, Korchmaros, \& Oppenheim, 2012). Selanjutnya, secara khusus Smith dkk. (2008) mengkonseptualisasi cyberbullying sebagai suatu tindakan agresif yang disengaja, yang dilakukan oleh kelompok atau individu, menggunakan media elektronik, secara berulang kali dan dari waktu ke waktu terhadap korban yang tidak dapat dengan mudah membela dirinya sendiri. Kemudian, Kowalski, Limber dan Agatston (2012) mendefinisikan cyberbullying sebagai tindakan agresi yang dilakukan kepada orang lain melalui email, sms, di chat room, di situs web, atau melalui pesan digital atau gambar yang dikirimkan ke telepon seluler.

Tempat di mana cyberbullying paling mungkin terjadi biasanya mencerminkan bentuk teknologi yang paling populer dalam mode pada waktu tertentu untuk kelompok usia tertentu (Kowalski \& Limber, 2013). Terlepas dari bentuk dan tempat, sifat dasar cyberbullying tetap sama seperti traditional bullying yaitu sebagai sebuah tindakan agresif yang dimaksudkan untuk menyakiti individu lain.

Cyberbullying mirip dengan traditional bullying dalam beberapa hal. Seperti halnya yang terjadi pada traditional bullying, cyberbullying juga merupakan sebuah tindakan agresi yang menyebabkan kerugian pada orang lain, yang biasanya dilakukan secara berulang dari waktu ke waktu, dan terjadi di antara individu yang hubungannya dicirikan oleh ketidakseimbangan 
kekuasaan (Kowalski, Giumetti, Schroeder, \& Lattanner, 2014; Kowalski dkk., 2012). Dalam hal ini, ketidakseimbangan kekuasaan dapat dilihat dari perbedaan dalam hal fisik maupun status sosial.

Terlepas dari kesamaan yang dimiliki oleh traditional bullying dan cyberbullying, kedua hal ini juga berbeda satu sama lain dalam beberapa hal. Pertama, traditional bullying yang terjadi di sekolah, hanya terjadi selama berada di sekolah saja (Rosen, DeOrnellas, \& Scott, 2017). Namun, berbeda dengan cyberbullying, yang dapat terjadi kapan saja dan di mana saja (Kowalski \& Morgan, 2017). Dengan demikian, korban cyberbullying jauh lebih rentan dibandingkan dengan traditional bullying, karena setiap saat ia bisa saja mendapatkan hal yang tidak menyenangkan dari orang lain.

Berdasarkan hasil penelitian internasional, cyberbullying tercatat memiliki kerugian psikologis terhadap korban (González-Cabrera, Calvete, León-Mejía, Pérez-Sancho, \& Peinado, 2017; Gualdo, Hunter, Durkin, Arnaiz, \& Maquilón, 2015; Hase, Goldberg, Smith, Stuck, \& Campain, 2015; Kaya \& Bicen, 2016; Na, Dancy, \& Park, 2015; O'Keeffe \& Clarke-Pearson, 2011). Berbeda halnya yang terjadi di Indonesia, menjadi salah satu korban cyberbullying dalam media sosial di Indonesia itu cukup unik, karena efeknya bisa menjadi viral dan terkenal (Akbari \& Falopenia, 2017; Mutma, 2017; Natalia, 2016; Widiastuti, 2016). Beberapa contoh yang dialami oleh Awkarin dan Younglex, mereka mengawali karier menjadi seorang artis dengan diawali dengan posisi sebagai korban cyberbullying (Mutma, 2017).

Sebagai keuntungan dari menjadi viral dan terkenal, korban cyberbullying di Indonesia secara sekejap dapat menjadi artis dengan cara yang cukup instant, yaitu menjadi selebgram dan YouTuber (Mutma, 2017). Hal ini sangat berpengaruh terhadap pendapatan finansial yang mereka dapatkan setiap bulannya. Fenomena berikutnya, terjadi pada salah satu generasi $\mathrm{Z}$ Indonesia yaitu Bowo Allpennliebe, yang menjadi mendadak terkenal karena selalu mendapatkan ujaran kebencian atau cyberbullying dari para netizen (Susilowati, 2018). Fenomena ini membuat semakin banyak para remaja millennials dan $\mathrm{Z}$ yang berupaya mengikuti jejak para selebgram dan
YouTuber pendahulu, bahwa melalui "sensasi" dan rekayasa menjadi korban cyberbullying merupakan salah satu cara yang paling ampuh agar menjadi viral dan terkenal (Akbari \& Falopenia, 2017; Widiastuti, 2016).

Kemudian, apakah trend di Indonesia akan bergeser bahwa untuk menjadi viral dan terkenal, orang-orang rela melakukan rekayasa agar menjadi korban cyberbullying? Fenomena ini membuat persepsi baru bahwa semakin di-bully, maka akan semakin viral dan terkenal. Semakin viral dan terkenal, maka akan semakin sejahtera.

Maka, dipandang cukup penting untuk membahas secara lebih mendalam mengenai fenomena unik mengenai cyberbullying yang terjadi di Indonesia. Kajian ini akan menjadi sebuah kajian yang bermanfaat dan memiliki kebaruan dalam konteks cyberbullying di dalam budaya Indonesia, karena sampai saat ini belum ada yang membahasnya. Namun dalam hal ini, penulis akan membatasi pembahasan dengan hanya menjawab pertanyaan-pertanyaan berikut ini:

1. Dampak negatif psikologis seperti apakah yang didapatkan oleh para korban cyberbullying?

2. Dampak positif psikologis seperti apakah yang didapatkan setelah menjadi viral dan terkenal?

\section{Metode Penelitian}

\section{Kriteria Inklusi dan Eksklusi}

Untuk dimasukkan dalam ulasan ini, artikelartikel yang dikaji harus mengeksplorasi perspektif korban cyberbullying yang dikaji berdasarkan dampak negatif dan positif yang didapatkan. Artikel-artikel yang didapatkan secara inklusi harus berdasarkan kajian yang meneliti tentang remaja sebagai responden atau partisipan. Jika terdapat responden atau partisipan orangtua, maka artikel tersebut termasuk ke dalam artikel yang eksklusi.

\section{Prosedur Pencarian yang Sistematis}

Pencarian sistematis dilakukan di enam basis data elektronik: Google Scholar, Springer Link, ProQuest, Ebsco Host, Cambridge Core, dan Taylor and Francis Online, selama Oktober 2018. 
Pencarian dibatasi pada artikel-artikel berbahasa Inggris dan Indonesia secara lengkap yang diterbitkan sejak tahun 2011. Pada semua lima basis data elektronik di atas, penulis melakukan pencarian artikel-artikel dengan menggunakan kombinasi keyword sebagai berikut: bull* DAN/ATAU victim*; cyberbullying* DAN/ATAU perundungan online*; negative impact* DAN/ATAU positive impact*; viral* DAN/ATAU

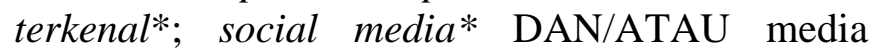
sosial.

\section{Ekstraksi Data dan Analisis}

Dengan menggunakan prosedur pencarian yang sistematis seperti disebutkan di atas, terdapat sejumlah 22 artikel yang teridentifikasi sesuai untuk dimasukkan dalam tinjauan literatur ini. Penentuan database, daftar referensi, dan pencarian artikel jurnal dilakukan oleh penulis, dan analisis data dilakukan juga oleh penulis. Analisis data dilakukan dengan melakukan pembacaan secara menyeluruh dari setiap studi, di mana bagian teks yang relevan disorot untuk mengekstrak temuan kunci yang menjadi pokok dalam tinjauan literatur ini. Interpretasi dan temuan ini dikelompokkan ke dalam kategori tematik; kategori-kategori ini kemudian direferensikan lintas di 22 studi untuk mengidentifikasi tema-tema umum.

\section{Hasil Penelitian dan Diskusi}

\section{Karakteristik Partisipan}

Alhujailli dan Karwowski (2018) dan Best, Manktelow, dan Taylor (2014), merupakan literatur review. Brooks (2015) menggunakan partisipan remaja sebanyak 139. Ciucci, Baroncelli, dan Nowicki (2014), menggunakan sebanyak 526 siswa sekolah menengah atas. Cowie (2013), menggunakan partisipan sebanyak 23.420 remaja. Drennan, Brown, dan Sullivan Mort (2011), tidak menyebutkan jumlah remaja yang dijadikan responden. Erreygers et al. (2018), menggunakan sebanyak 136 remaja, Gualdo et al. (2015), menggunakan sebanyak 1353 remaja Spanyol. Halpern, Piña dan Vásquez (2017), menggunakan sebanyak 7000 siswa. Hase et al. (2015), menggunakan 1225 remaja dari lima sekolah menengah dan tinggi di Southern Oregon (586 perempuan, 632 laki-laki, 7 tidak melaporkan gender). Kaya dan Bicen (2016), menggunakan 362 siswa SMA dari level 9 hingga 12.

Mawardah dan Adiyanti (2014), menggunakan siswa SMP Negeri "S" kelas VII dan VIII, usia 1214 tahun, dan menggunakan teknologi informasi minimal 2 tahun. Moore (2012), menggunakan 901 siswa sebagai responden. Na, Dancy, dan Park (2015), menggunakan sebanyak 121 siswa. Navarro et al. (2015), menggunakan anak-anak sekolah 10-12 tahun ( $\mathrm{n}=1058)$. Newland, Mourlam, dan Strouse (2018), menggunakan (N = 22) di daerah pedesaan dan perkotaan di Amerika Serikat bagian Barat Tengah, sebagai bagian yang lebih besar studi kualitatif komparatif multinasional tentang kesejahteraan anak-anak. Park et al. (2017), menggunakan sebanyak 2016 pemuda Korea Selatan. Perren, dan GutzwillerHelfenfinger (2012), menggunakan 564 siswa. Souza, Veiga Simão, Ferreira dan Ferreira (2017), menggunakan 979 siswa. Suciartini dan Sumartini (2018), subyek penelitiannya adalah pengguna akun media sosial di Facebook, Path, BBM, Twitter, Yahoo, dan sebagainya namun tidak disebutkan secara eksplisit mengenai jumlahnya. Uusitalo-Malmivaara dan Lehto (2016), menggunakan 700 siswa. Varela, Guzmán, Alfaro, dan Reyes (2018), menggunakan sampel dari 497 pemuda yang terdaftar di kelas 9 hingga 12 sekolah negeri dan swasta di berbagai distrik Chili. Terakhir, You, Lee, dan Kim (2016), menggunakan sampel dari 1347 remaja Korea.

\section{Temuan Utama}

Dampak Negatif secara Psikologis Korban Cyberbullying

Terdapat 4 tema besar yang teridentifikasi dalam hal ini, yaitu: (1) emotional regulation, (2) stress, (3) depression, dan (4) loneliness.

\section{Emotional Regulation}

Temuan yang didapatkan oleh Suciarti dan Sumartini (2018), Mawardah dan Adiyanti (2014) menjelaskan bahwa dampak negatif secara psikologis korban cyberbullying ialah terjadi emotional regulation yang rendah, karena biasanya terjadi emosi yang tidak terkontrol, emosi yang memuncak, dan cenderung terlalu 
bersedih. Hal ini senada dengan temuan yang dilakukan juga oleh Alhujailli dan Karwowski (2018), Ciucci et al. (2014), Cowie (2013), Gualdo et al. (2015), dan Na et al. (2015).

\section{Stress}

Temuan yang didapatkan oleh Hase et al. (2015), didapatkan bahwa para korban cyberbullying akan mengalami stress yang cukup serius. Hal ini disebabkan bahwa korban cyberbullying selalu mendapatkan tekanan dari para pelaku bully tanpa melihat waktu dan tempat. Hal ini senada dengan temuan yang dilakukan oleh Park et al. (2017).

\section{Depression}

Temuan yang didapatkan oleh UusitaloMalmivaara dan Lehto (2016), juga menjelaskan bahwa para remaja yang menjadi korban cyberbullying akan cenderung memiliki depression yang cukup tinggi, sehingga banyak yang memerlukan bantuan kesehatan mental.

\section{Loneliness}

Temuan yang didapatkan oleh Halpern et al. (2017), mendapatkan temuan menarik bahwa pada akhirnya para korban cyberbullying akan merasa loneliness karena merasa bahwa "dunia" tidak menerima keberadaan dirinya lagi.

\section{Tabel 1. Dampak Negatif secara Psikologis Korban Cyberbullying}

Dampak Negatif secara Psikologis Korban Cyberbulling

Indikator
1. Emotional Regulation

2. Stress

3. Depression

4. Loneliness
Studi

Suciarti dan Sumartini (2018), Mawardah dan

Adiyanti (2014), Alhujailli dan Karwowski

(2018), Ciucci et al. (2014), Cowie (2013),

Gualdo et al. (2015), dan Na et al. (2015).

Hase et al. (2015), Park et al. (2017).

Uusitalo-Malmivaara dan Lehto (2016).

Halpern et al. (2017).
Dampak Positif secara Psikologis Korban Cyberbullying yang menjadi Viral dan Terkenal

Terdapat 3 tema besar yang teridentifikasi dalam hal ini, yaitu: (1) happiness, (2) life satisfaction, dan (3) subjective wellbeing.

\section{Happiness}

Berdasarkan kajian yang dilakukan oleh Kaya \& Bicen (2016), dikatakan bahwa efek dari menjadi viral dan terkenal di sosial media akan meningkatkan happiness para kaum anak muda. Hal ini berkaitan dengan penerimaan yang orang lain berikan terhadap diri mereka, bahwasanya banyak orang lain di luar sana yang menyukai diri mereka walaupun belum terlalu mengenal diri mereka seutuhnya. Hal ini juga senada dengan temuan yang dilakukan oleh Erreygers et al. (2018), dan Uusitalo-Malmivaara dan Lehto (2016).

\section{Life Satisfaction}

Berdasarkan hasil penelitian yang dilakukan oleh Navarro et al. (2015), didapatkan bahwa life satisfaction seorang remaja akan meningkat ketika mendapatkan perhatian secara khusus oleh peer-groupnya di sosial media. Hal ini juga senada dengan temuan yang dilakukan oleh Moore (2012), Varela et al. (2018), dan Souza et al. (2017).

\section{Subjective Wellbeing}

Berdasarkan hasil kajian yang dilakukan oleh Best et al. (2014), didapatkan juga bahwa subjective wellbeing seorang remaja akan meningkat berdasarkan dampak sosial media yang mereka miliki. Mereka mendapatkan sesuatu yang mereka dapatkan di usia muda, seperti ketenaran, kemapanan, hadiah, dan pujian. Hal ini juga senada dengan temuan yang dilakukan oleh Brooks (2015), Cowie (2013), Drennan et al. (2011), Halpern et al. (2017), 
Newland et al. (2018), dan Souza et al. (2017).

Tabel 2. Dampak Positif secara Psikologis Korban Cyberbullying yang menjadi Viral dan Terkenal

\begin{tabular}{ll}
\hline \multicolumn{2}{c}{ Dampak Positif secara Psikologis Korban Cyberbulling yang menjadi Viral dan Terkenal } \\
\hline Indikator & Studi \\
1. Happiness & Kaya \& Bicen (2016), Erreygers et al. (2018), \\
& dan Uusitalo-Malmivaara dan Lehto (2016). \\
2. Life Satisfaction & Navarro et al. (2015), Moore (2012), Varela et al. \\
& (2018), dan Souza et al. (2017). \\
3. Subjective Wellbeing & Best et al. (2014), Brooks (2015), Cowie (2013), \\
& Drennan et al. (2011), Halpern et al. (2017), \\
& Newland et al. (2018), dan Souza et al. (2017). \\
\hline
\end{tabular}

\section{Kesimpulan}

Berdasarkan kajian literatur ini, cyberbullying tercatat memiliki kerugian dan keuntungan secara psikologis terhadap korbannya. Di Indonesia, menjadi salah satu korban cyberbullying dalam media sosial di Indonesia itu cukup unik, karena efeknya bisa menjadi viral dan terkenal (Akbari \& Falopenia, 2017; Mutma, 2017; Natalia, 2016; Widiastuti, 2016).

Sebagai keuntungan dari menjadi viral dan terkenal, korban cyberbullying di Indonesia secara sekejap dapat menjadi artis dengan cara yang cukup instant, yaitu menjadi selebgram dan YouTuber (Mutma, 2017). Hal ini sangat berpengaruh terhadap pendapatan finansial yang mereka dapatkan setiap bulannya. Fenomena berikutnya, terjadi pada salah satu generasi $\mathrm{Z}$ Indonesia yaitu Bowo Allpennliebe, yang menjadi mendadak terkenal karena selalu mendapatkan ujaran kebencian atau cyberbullying dari para netizen (Susilowati, 2018). Fenomena ini membuat semakin banyak para remaja millennials dan $\mathrm{Z}$ yang berupaya mengikuti jejak para selebgram dan YouTuber pendahulu, bahwa melalui "sensasi" dan rekayasa menjadi korban cyberbullying merupakan salah satu cara yang paling ampuh agar menjadi viral dan terkenal (Akbari \& Falopenia, 2017; Widiastuti, 2016).

Maka, dipandang cukup penting untuk membahas secara lebih mendalam mengenai fenomena unik mengenai cyberbullying yang terjadi di Indonesia. Kajian ini akan menjadi sebuah kajian yang bermanfaat dan memiliki kebaruan dalam konteks cyberbullying di dalam budaya Indonesia, karena sampai saat ini belum ada yang membahasnya.

Namun, hal yang perlu digarisbawahi dalam konteks temuan kajian litertur ini, bahwasanya dampak negatif (kerugian) yang didapatkan oleh remaja ketika menjadi korban cyberbullying ialah lebih banyak dibandingkan dengan dampak postif (keuntungan) yang didapatkan oleh remaja ketika menjadi korban cyberbullying.

\section{Keterbatasan Literatur}

Kajian literatur yang telah disusun ini tidak hanya mencakup hasil penelitian yang dilakukan di Indonesia saja, namun juga yang telah dilakukan secara internasional. Hal ini yang menjadi batasan untuk mengidentifikasi secara khusus yang terjadi pada remaja korban cyberbullying di Indonesia yang menjadi viral dan terkenal.

\section{Arah untuk Penelitian Masa Depan}

Berdasarkan keterbatasan yang ada, topik ini sangat menarik untuk dikaji lebih lanjut agar mendapatkan informasi yang lebih mendalam lagi mengenai dampak negatif maupun positif sebagai korban cyberbullying di Indonesia yang menjadi viral dan terkenal.

\section{Daftar Pustaka}

Akbari, T. T., \& Falopenia, A. C. (2017). Personal image generasi millennial korban cyberbullying pada akun instagram dan Ask Fm di Jakarta. Prosiding Konferensi 
Nasional Komunikasi, 1(1), 368-378.

Alhujailli, A., \& Karwowski, W. (2018, July). Emotional and Stress Responses to Cyberbullying. In International Conference on Applied Human Factors and Ergonomics (pp. 33-43). Springer, Cham.

Best, P., Manktelow, R., \& Taylor, B. (2014). Online communication, social media and adolescent wellbeing: A systematic narrative review. Children and Youth Services Review, 41, 27-36.

Brooks, S. (2015). Does personal social media usage affect efficiency and wellbeing?. Computers in Human Behavior, 46, 26-37.

Ciucci, E., Baroncelli, A., \& Nowicki, S. (2014). Emotion perception accuracy and bias in face-to-face versus cyberbullying. The Journal of genetic psychology, 175(5), 382-400.

Cowie, H. (2013). Cyberbullying and its impact on young people's emotional health and well-being. The Psychiatrist, 37(5), 167170 .

Drennan, J., Brown, M. R., \& Sullivan Mort, G. (2011). Phone bullying: impact on selfesteem and well-being. Young Consumers, 12(4), 295-309.

Erreygers, S., Vandebosch, H., Vranjes, I., Baillien, E., \& De Witte, H. (2018). Feel Good, Do Good Online? Spillover and Crossover Effects of Happiness on Adolescents' Online Prosocial Behavior. Journal of Happiness Studies, 118.

González-Cabrera, J., Calvete, E., León-Mejía, A., Pérez-Sancho, C., \& Peinado, J. M. (2017). Relationship between cyberbullying roles, cortisol secretion and psychological stress. Computers in Human Behavior, 70, 153-160.
Gualdo, A. M. G., Hunter, S. C., Durkin, K., Arnaiz, P., \& Maquilón, J. J. (2015). The emotional impact of cyberbullying: Differences in perceptions and experiences as a function of role. Computers \& Education, 82, 228-235.

Gualdo, A. M. G., Hunter, S. C., Durkin, K., Arnaiz, P., \& Maquilón, J. J. (2015). The emotional impact of cyberbullying: Differences in perceptions and experiences as a function of role. Computers \& Education, 82, 228-235.

Halpern, D., Piña, M., \& Vásquez, J. (2017). Loneliness, personal and social well-being: towards a conceptualization of the effects of cyberbullying/Soledad, bienestar social e individual: hacia una conceptualización de los efectos del cyberbullying. Cultura $y$ Educación, 29(4), 703-727.

Hase, C. N., Goldberg, S. B., Smith, D., Stuck, A., \& Campain, J. (2015). Impacts of traditional bullying and cyberbullying on the mental health of middle school and high school students. Psychology in the Schools, 52(6), 607-617.

Hase, C. N., Goldberg, S. B., Smith, D., Stuck, A., \& Campain, J. (2015). Impacts of traditional bullying and cyberbullying on the mental health of middle school and high school students. Psychology in the Schools, 52(6), 607-617.

Kaya, T., \& Bicen, H. (2016). The effects of social media on students' behaviors; Facebook as a case study. Computers in Human Behavior, 59, 374-379.

Kaya, T., \& Bicen, H. (2016). The effects of social media on students' behaviors; Facebook as a case study. Computers in Human Behavior, 59, 374-379.

Kowalski, R. M., \& Limber, S. P. (2013). Psychological, physical, and academic correlates of cyberbullying and traditional bullying. Journal of Adolescent Health, 53, S13-S20. 
Kowalski, R. M., \& Morgan, M. E. (2017). Cyberbullying in Schools. The Wiley Handbook of Violence and Aggression, 112.

Kowalski, R. M., Giumetti, G. W., Schroeder, A. W., \& Lattanner, M. R. (2014). Bullying in the digital age: A critical review and meta-analysis of cyberbullying research among youth. Psychological Bulletin, 140, 1073-1137. doi:10.1037/a0035618

Kowalski, R. M., Limber, S. E., \& Agatston, P. W. (2012). Cyberbullying: Bullying in the digital age ( $2^{\text {nd }}$ ed.). Malden, MA: WileyBlackwell.

Mawardah, M., \& Adiyanti, M. G. (2014). Regulasi emosi dan kelompok teman sebaya pelaku cyberbullying. Jurnal psikologi, 41(1), 60-73.

Moore, P. M. (2012). Electronic bullies, victims, and bully-victims: An examination of life satisfaction in middle school students (Doctoral dissertation, University of South Carolina).

Mutma, F. S. (2017). Pemaknaan followers terhadap gaya hidup selebgram: Studi resepsi pada viewers vlog akun Youtube Karin Novilda. Prosiding Konferensi Nasional Komunikasi, 1(1), 152-165.

Na, H., Dancy, B. L., \& Park, C. (2015). College student engaging in cyberbullying victimization: Cognitive appraisals, coping strategies, and psychological adjustments. Archives of Psychiatric Nursing, 29(3), 155-161.

Na, H., Dancy, B. L., \& Park, C. (2015). College student engaging in cyberbullying victimization: Cognitive appraisals, coping strategies, and psychological adjustments. Archives of Psychiatric Nursing, 29(3), 155-161.

Natalia, E. C. (2016). Remaja, media sosial, dan cyberbullying. Jurnal Ilmiah Komunikasi, 5(2), 119-139.
Navarro, R., Ruiz-Oliva, R., Larrañaga, E., \& Yubero, S. (2015). The impact of cyberbullying and social bullying on optimism, global and school-related happiness and life satisfaction among 1012-year-old school children. Applied Research in Quality of Life, 10(1), 15-36.

Newland, L. A., Mourlam, D., \& Strouse, G. (2018). A Phenomenological Exploration of the Role of Digital Technology and Media in Children's Subjective Well-Being. Child Indicators Research, 11(5), 1563-1583.

O'Keeffe, G. S., \& Clarke-Pearson, K. (2011). Clinical report - the impact of social media on children, adolescents, and families. Pediatrics, peds-2011.

Olweus, D. (2012). Cyberbullying: An overrated phenomenon? European Journal of Developmental Psychology, 9, 520-538. doi:10.1080/17405629.2012.682358.

Park, S., Lee, Y., Jang, H., \& Jo, M. (2017). Violence victimization in Korean adolescents: risk factors and psychological problems. International journal of environmental research and public health, 14(5), 541.

Perren, S., \& Gutzwiller-Helfenfinger, E. (2012). Cyberbullying and traditional bullying in adolescence: Differential roles of moral disengagement, moral emotions, and moral values. European Journal of Developmental Psychology, 9(2), 195-209.

Rosen, L. H., DeOrnellas, K., \& Scott, S. R. (2017). Bullying in School: Perspectives from School Staff, Students, and Parents. Texas: Springer.

Smith, P. K., del Barrio, C., \& Tokunaga, R. (2012). Definitions of bullying and cyberbullying: How useful are the terms? In S. Bauman, D. Cross, \& J. Walker (Eds.), Principles of cyberbullying research: Definition, measures, and methods (pp. 2940). Philadelphia, PA: Routledge. 
Smith, P. K., Mahdavi, J., Carvalho, M., Fisher, S., Russell, S., \& Tippett, N. (2008). Cyberbullying: Its nature and impact in secondary school pupils. Journal of Child Psychology and Psychiatry, 49, 376-385. doi:10.1111/j.1469-7610.2007.01846.x

Souza, S. B., Veiga Simão, A. M., Ferreira, A. I., \& Ferreira, P. C. (2017). University students' perceptions of campus climate, cyberbullying and cultural issues: implications for theory and practice. Studies in Higher Education, 116.

Suciartini, N. N. A., \& Sumartini, N. L. P. U. (2018). Verbal Bullying Dalam Media Sosial Ditinjau Dari Perspektif Penyimpangan Prinsip Kesantunan Berbahasa. Ganaya: Jurnal Ilmu Sosial dan Humaniora, 1(1), 104-134.

Susilowati, S. (2018). Pemanfaatan aplikasi Tiktok sebagai personal branding di Instagram: Studi deskriptif kualitatif pada akun @ bowo_allpennliebe.Jurnal
Komunikasi, 9(2), 27-36.

Uusitalo-Malmivaara, L., \& Lehto, J. E. (2016). Happiness and depression in the traditionally bullied and cyberbullied 12year-old. Open Review of Educational Research, 3(1), 35-51.

Varela, J. J., Guzmán, J., Alfaro, J., \& Reyes, F. (2018). Bullying, Cyberbullying, Student Life Satisfaction and the Community of Chilean Adolescents. Applied Research in Quality of Life, 1-16.

Widiastuti, T. (2016). Rekayasa gambar diri remaja dalam mencapai pengakuan sosial di Instagram. Jurnal Ilmu Komunikasi, 14(3), 215-224.

Ybarra, M. L., Boyd, D., Korchmaros, J. D., \& Oppenheim, J. (2012). Defining and measuring cyberbullying within the larger context of bullying victimization. Journal of Adolescent Health, 51, 53-58. doi:10.1016/j.jadohealth.2011.12.031 